https://doi.org/10.52837/27382702-2021-34.2-11

\title{
THE INTRODUCTION OF NET-PLATFORM-CENTRIC WARFARE IN THE CHINESE ARMY (PLA)*
}

\author{
Artsrun Hovhannisyan
}

\begin{abstract}
It is no surprise that just like the previous years, this year as well China has expanded its military budget, put another ship to sea, demonstrated new weaponary at the military parade, etc. For the last two decades, all the combat arms of the Chinese army has been developing at a high rate. Many authors claim very specific reasons for the Chinese armaments especially highlighting the conflicts with its immediate neighbors.

From a geopolitical point of view, an interesting balance of power is being formed in the East. It's been several years now that there are some precise problems in China-Japan conflict related to the power over some islands. China actively builds artificial islands which can serve as military bases far away from its shores approximately at an operative depth. And this matter deeply concerns the Philippines and Vietnam.

In this light, it would be very interesting to study the balance of forces in the region and to analyze the American military doctrine on the one hand and the Chinese specific military and military-political attempts to appose it on the other hand. It is common knowledge that in political and professional circles in the USA are concerned about the actions and capabilities of China and Russia, which can considerably restrict the US access to key regions of Eurasia: Today, China and Russia have great potential to influence on the traditional American Net-platform weaponary, Air Forces, Navy, command and control networks, and even the orbital groupings.

The two countries mentioned above, which are perceived as potential adversaries in the USA, strive to reach the level of the American military by all possible means and develop powerful techonologies. Russia and especially China are designing powerful satellite systems, various long-range missiles, fighter jets, UAVs, etc. New Electronic Warfare (EW) systems are being developed, to suppress or weaken the command and management systems of the US or its allies. The People's Liberation Army (PLA) of China also has the capacity to destroy settelites, disrupt extraterrestrial intelligence, wreck command and control networks, etc. According to experts, there is no guarantee that the armed forces of the USA can ensure reliable and secure communication and conncetion during conflicts on the theater of military operations, in particular on operational and strategic levels.
\end{abstract}

Keywords: Army, China, USA, PLA, supremacy, air force, navy, missile, fighter, defense, offensive, attack, strikes.

\footnotetext{
${ }^{*}$ The article was submitted on November 1, 2021. The article was reviewed on November 14, 2021.
} 


\section{Issues of the US bases}

The US land bases are considered vulnerable and easy to be attacked as their number is scarce in the region, and their positions are identified. Thus, they can be attacked not only by the traditional offensive armaments, but also by the terrorist and other capabilities. Possible attacks carried out by the Chinese army on the American installations located in Korea, Japan, the Phillipines, and other parts in the region are considered particularly problematic ${ }^{1}$. Some experts claim, that these attacks can also be extremely dangerous for Carrier Strike Groups (CSG) as the CSG strikes may not be as effective having in consideration that the $3^{\text {rd }}$ artillery coprs of the Chinese army alone has formed seven brigades of short-range ballistic missiles, three brigades of medium-range ballistic missiles and three brigades of ground-based cruise missiles ${ }^{2}$. Based on various estimates, the number of Chinese short-range missiles for close range operations exceeds 1000 units, and the "CJ$10 / 20$ " "H-6K" bombers armed with cruise missiles are able to reach as far as the American bases called "Apra Harbor" and "Anderson". Also, PLA is currently developing ballistic missiles with the range of 3000-5000 km "beyond the second chain of islands": Japan, Guam and the Mariana Islands, up to Indonesia, increasing its capabilities closer to that of high-precision strikes ${ }^{4}$. According to the report by the U.S.-China Economic and Security Review, 2013 "PLA is developing its striking capabilities rapidly and multidirectionally towards the American installations, and bases of Navy and Air Forces located in the Pacific, including Guam $^{5}$. The reconnaissance and strike networking systems of the US potential adversaries include torpedoes, air, sea and ground-based anti-ship cruise missiles, as well as ballistic anti-ship missiles with regard to China and Iran. Chinese "DF21D" ballistic missiles (aircraft carrier "killer") have more than $1500 \mathrm{~km}$ of range, which enables their attack on large warships including aircraft carriers in the Western Pacific ${ }^{6}$. As claimed by numerous experts, China would be increasing the range of its "DF-26" anti-ship ballistic missiles up to $4000 \mathrm{~km}$ by $2015^{7}$. During its

\footnotetext{
${ }^{1}$ PLA Second Artillery Corps 2004: 401.

${ }^{2}$ Christman, Ron 2014: 31-34.

${ }^{3}$ Yoskihara, Toshi. - Chinese Missile Strategy and the U.S. Naval Presence in Japan: The Operational View from Beijing, Naval War College Review, Vol 63, No 3, Summer 2010. 30

November. 2016. https://www.usnwc.edu/getattachment/69198ee2-edc2-4b82-8f85-

568f80466483/Chinese-Missile-Strategy-and-the-U-S--Naval-Presen

${ }^{4}$ OSD, 2013, 37; Erickson, Andrew. - Beijing's Aerospace Revolution, $\|$ in Andrew Erickson and Lyle Goldstein, (Eds.), Chinese Aerospace Power. Annapolis, MD: Naval Institute Press, 2011, p. 7.

${ }^{5}$ U.S.-China Economic and Security Review Commission. 2013 Report to Congress. Washington, DC: GPO, November 20, 2013, p. 233. 30 November. 2016.

$<$ http://www.uscc.gov/Annual_Reports/2013-annual-report-congress>

${ }^{6}$ OSD, 2013, 5-6; O`Rourke, Ronald. China Naval Modernization: Implications for U.S. Navy Capabilities, RL33153, Congressional Research Service (CRS) Report for Congress, Washington, DC: CRS, February 2014, pp. 5-6. https://www.fas.org/sgp/crs/row/RL33153.pdf>

7 Chang, Amy and John Dotson. Indigenous Weapons Development in China's Military Modernization, Staff Research Report, Washington, DC: U.S.-China Economic and Security Review
} 
various military parades in 2018-2019, China demonstrated a wide range of such missile models. Moreover, they have also exhibited high-speed flying and evading combat units. For example, the much-talked-about "DF-ZF" battle block will be installed on the renowned anti-ship ballistic missiles. And in this case, it will be very hard to fight against these missiles ${ }^{8}$.

According to some experts on PLA, China was striving to increase the range of its conventional assets up to $8000 \mathrm{~km}$ by $2020^{9}$.

\section{Air Supremacy Issues}

Having in consideration the fact that China is creating artificial islands in the South China Sea which are insecure areas for Vietnam and the Philippines on the one hand, and has claims on Senkaku islands on the other hand, experts concluded that these islands can become large springboards for Chinese air forces, Navy and other services of Armed Forces. The situation grew especially tense by the fact that the Chinese 'YJ-26' counter stealth radar station was able to detect the fifthgeneration American "F-22" fighters ${ }^{10}$. In this regard, a number of American theorists share the same concerns as they believe that the most part of the aircraft of the US Air Forces have limited combat capabilities due to the lack of airfields within the areas close to the Theater of Military Operations (500-1000 miles). A solution to this problem could be the use of aerial refueling planes, even though this is also considered a failure-prone approach. For example, the combat range of the American groud-based fighters reaches up to 600 miles denpending on the type of the aircraft, weapons, and flight charecteristics. New capabilities of the Chinese side are full of serious consequesnces for the US Air Forces, as the operational range of some Chinese fighters without refueling is $950-1400 \mathrm{~km}$, wich according to experts, makes US tanker planes and fighters vulnerable ${ }^{11}$. Many experts think that the main threat to the US Air Forces and airborne weapons (AW), is a land and sea-based unified Air Defense (AD) system. Integration AD system becomes more predominant and reliable. Prevalance of a modern unified Air defense system makes the traditional American Air Force design problematic as the substantial majority of aircraft has little flying range and is not stealthy. The number of aircraft

Commission, April 5, 2012, p. 23; 30 November. 2016. Stokes, China's Evolving Conventional Strategic Strike Capability, p. 2.

8 Perrett, Sweetman; Fabey, Michael §U.S. Navy Sees Chinese HGV as Part of Wider Threat. . Aviation Week \& Space Technology. Retrieved 2018-12-14.

${ }^{9}$ Stokes, Mark. China's Evolving Conventional Strategic Strike Capability: The anti-ship ballistic missile challenge to U.S. maritime operations in the Western Pacific and beyond. Arlington, VA:

Project 2049 Institute, September 14, 2009, p. 2. 30 November. 2016.

$<$ http://project2049.net/documents/chinese_anti_ship_ballistic_missile_asbm.pdf $>$

10 17.11.14 Китайский радар YJ-26 способен обнаружить F-22,

http://www.militaryparitet.com/ttp/data/ic_ttp/7072/

11 2014-2043. Washington, DC: DoD, May 2013. 30 November. 2016. OSD, Quadrennial Defense Review 2014, p. 40.1 Ibid., pp. 29-30. 
with low visibility (B-2, F-22, RQ-170 Sentinel, etc.) comprises less than $10 \%$ of the US Air Force inventory ${ }^{12}$.

It is common sense that a possible clash between China and the US will mainly be between the Air Force and the Navy with the minimal use of ground troops. Groud troops, in their turn will be in the form of landing force: it means that the success of those landing troops will depend on the dominance of navy and air force. Combat and logistic support of high tempo air operations is also problematic ${ }^{13}$. Detection, tracking and attacking of surface ships in the seas and oceans require not only a wide network of radars but also a creation of command, control and communication (C3) system, that collects, processes, unifies and distributes the data to the strike system by expediency. Thus, it is not about ordinary reconnaissance-strike systems but about networks the emergence of which in China has become a serous challenge for the United States throughout last two decades. For example, according to some estimates, China's reconnaissance-strike network now has the capability to detect and guide American surface warships not only in the South China Sea but also in the western part of the Pacific Ocean ${ }^{14}$. In fact, China is the second country after the US which is actively developing new generation equipment for net-platform-centric warfare both for technical usage and application. According to one of the naval experts, "Most probabaly by the year of 2030 we will have to admit that it might be possible to detect, identify and guide the surface ships a few hundred or even a few thousand miles away from the shore in case appropriate efforts are exerted to resolve a given problem ${ }^{15}$.",

The lounching distance of missiles without entering the engagement zone of the air defence in the western sector of the Pacific Ocean and the South China Sea, can exceed 1,500 miles. Accoring to some experts, it is 500 miles more than the range of 'BGM-109'"missiles' strikes on ground targets and almost three times superior to "F / A-18E /F Super Hornet" multipurpose fighter's operational radius without refueling.

In subsequent campaigns, when China's reconnaissance-strike network gets completely expanded and assigned to operational readiness, the US destroyers and cruisers armed with cruise missiles might get under attack during combat application of their main weapons. Similarly, if CSG have to maintain distance in order to avoid anti-ship ballistic missile attacks, the use of carrier aviation with combat payload, for both execution of combat mission and return to the estimated

\footnotetext{
${ }^{12}$ Kopp, Carlo. Evolving Technological Strategy in Advanced Air Defense Sys-tems, $\|$ Joint Forces Quarterly, Issue 57, 2nd Quarter 2010, p. 93.30 November. 2016.

$<$ http://www.dtic.mil/doctrine/jfq/jfq-57.pdf $>$

${ }^{13}$ Martinage, Toward 2014: 26-27.

14 2014-2043. Washington, DC: DoD, May 2013. 30 November. 2016. OSD, Quadrennial Defense Review 2014, p. 40.1 Ibid., p. 27.

${ }^{15}$ N. Friedman. The U.S. Navy of 2030, Defense, Spring 2012. 30 November. 2016.
} 
area will require several circles for air refueling ${ }^{16}$. Those are pretty negative opinions typical to some American centers of expertise when assessing the risks.

According to some experts, the situation is not good in the space domain as well. China is developing its capabilities of creating attack laser systems in order to carry out direct attacks (hit-to-kill), creating satellite interceprot aircrafts, directascent anti-satellite (ASAT) intercepts, and coorbital attackers ${ }^{17}$. The former director of National Intelligence J. Clapper noted: "Both Chinese and Russian servicemen realize the unique information benefits provided by space systems. Therefore, they develop capabilities to deny the use of space tos the US"18.

\section{Ground Forces of China}

For an extended period, the Chinese Armed Force development was chiefly in favour of Ground Force advancement. For the past twenty years or so Chinese Armed Forces have gone through an intensive development ${ }^{19}$. For the past twenty years, Chinese army almost completely has changed its armament, which was mostly of Soviet origin, from 1960-1970. Armamets were removed from the arsenal en masse; they were replaced by relatively new weapons, often based on the technology of the 2000s produced on their own in addition to relatively recent Soviet/Russian armaments and sometimes even weapons based on Western technologies. Today, the Chinese Army is the second largest army after the American Armed Forces which produces a large number of various UAVs, Highprecision weapons, and digital control systems ${ }^{20}$. Nowadays, Chinese Army is one of the first who obtains self-propelled anti-tank missiles, laser weapons, etc. Despite this, Chinese military-political leadership was aware of the fact that military reforms are not possible solely by weapons. After studying best practices of different armies worldwide, Chinese military-political leadership decided to follow the path of the symbiosis of American and Soviet army building. Hence, a new era of reforms began in $2016^{21}$, and only in one year, the Chinese Army had a

\footnotetext{
${ }^{16}$ Martinage, Toward 2014: 28.

${ }^{17}$ Shalal-Esa, Andrea. China's Space Activities Raising U.S. Satellite Concerns, Reuters, January 14, 2013; 30 November. 2016. Weeden, Brian. China's BX-1 Microsatellite: A Litmus Test for Space Weaponization,\| The Space Review, October 20, 2008. 30 November. 2016.

18 J. Clapper. Director of National Intelligence. Worldwide Threat Assessment of the U.S. Intelligence Community, Statement for the Senate Select Committee on Intelligence, January 29, 2014, p. 7. 30 November. 2016.

${ }_{19}$ Chapter 8, PLA Ground Forces, by Dennis J Blasko, in The People's Liberation Army as Organisation, RAND, CF182.
}

${ }^{20}$ D. J. Blasko, §PLA Force Structure: A 20-Year Retrospective!, in Seeking Truth from Facts, ed. James C. Mulvenon and Andrew N.D. Yang (Santa Monica, CA: RAND, 2001); D. J. Blasko, Tradition and Transformation in the PLA, 2013, Table 4.3, p. 91; China Takes Bold Steps Toward Military Reform. Jan 11, 2016. https://worldview.stratfor.com/article/china-takes-bold-steps-towardmilitary-reform

${ }^{21}$ China Takes Bold Steps Toward Military Reform. Jan 11, 2016.

https://worldview.stratfor.com/article/china-takes-bold-steps-toward-military-reform 
newly established structure ${ }^{22}$. As mentioned previously, all Armed Forces are commanded by the Central Military Council (CMC), which includes all the governing bodies. Furthermore, all the forces and means are its subjects. There is no General Staff in the Chinese Army; intead its operations were consolidated into the Joint Staff Department of the Central Military Commission. All Armed Forces were devided into five theater commands instead of the previous military regions ${ }^{23}$ :

1. Northern Theater Command ; the headquarters is located in Shanhai.

2. Central Theater Command; the headquarters is located in Beijing.

3. Western Theater Command; the headquarters is located in Chengdu.

4. Southern Theater Command; the headquarters is located in Guangzhou.

5. Eastern Theater Command; the headquarters is located in Nanjing.

All five commands mentioned above are the commanders-in-chief of the supreme operational and strategic unifications ${ }^{24}$, who have absolute leadership over all Chinese combat arms, except the rocket troops and strategic support forces. The latter is a new military type in the Chinese army. The last two combat arms are also directly under the command of CMC. Rocket troops which are now developping at an increadible speed, form nine seperate armies ${ }^{25}$.

Currently, the Northern Theatre Command shares borders with North Korea, Russia and Mongolia ${ }^{26}$. The Northern Theater Command consists of the following components ${ }^{27}$ :

- $78^{\text {th }}$ Group Army composed of the $8^{\text {th }}, 48^{\text {th }}, 65^{\text {th }}, 115^{\text {th }}, 202^{\text {nd }}$ Motorised Infantry Brigades, $78^{\text {th }}$ Artillery Brigade, one Army Aviation Brigade and other combat support brigades.

- $79^{\text {th }}$ Group Army composed of the $46^{\text {th }}, 116^{\text {th }}, 119^{\text {th }}, 190^{\text {th }}, 191^{\text {st }}, 200^{\text {th }}$

- Motorised Infantry Brigades, the $79^{\text {th }}$ Artillery Brigade one Army Aviation Brigade and other combat support brigades.

- $80^{\text {th }}$ Group Army composed of the $47^{\text {th }}, 69^{\text {th }}, 118^{\text {th }}, 138^{\text {th }}, 199^{\text {th }}$, and $203^{\text {rd }}$ motorised infantry brigades, $80^{\text {th }}$ artillery brigade, one army aviation brigade and other combat support brigades.

\footnotetext{
22 А. Храмчихин. Новая Великая китайская стена. 20.10.2017. http://nvo.ng.ru/forces/2017-1020/1 970 china.html

${ }^{23}$ K. NAKKAZAWA. Xi declares victory over old rivals Jiang, Hu. FEBRUARY 11, 2016. https://asia.nikkei.com/Features/Chin a-up-close/Xi-declares-victory-over-old-rivals-Jiang-Hu

${ }^{24}$ President Xi announces establishment of five PLA theater commands. 2016-February-1. http://eng.mod.gov.cn/TopNews/2016-02/01/content_4638960.htm

${ }^{25}$ China Takes Bold Steps Toward Military Reform. Jan 11, 2016. https://worldview.stratfor.com/article/china-takes-bold-steps-toward-military-reform ${ }^{26} \mathrm{http}$ ://china-defense.blogspot.com/2017/09/pla-orbat-update-northern-theater.html;

А. Храмчихин. Новая Великая китайская стена. 20.10.2017. http://nvo.ng.ru/forces/2017-1020/1_970_china.html

${ }^{27} \mathrm{http}$ ://china-defense.blogspot.com/2017/09/pla-orbat-update-northern-theater.html;

The Military Balance 2018. Routledge, pp. 249-259.
} 
In addition, the $11^{\text {th }}$ border guard brigade, and four other border protection brigades are under the command of the Northern Theater. Air force of the Northern Theater consists of six aviation divisions: the $1^{\text {st }}, 5^{\text {th }}, 11^{\text {th }}, 12^{\text {th }}, 16^{\text {th }}, 21^{\text {st }}$, altogether 13 air regiment and 9 separate air brigades: the $2^{\text {nd }}, 3^{\text {rd }}, 15^{\text {th }}, 31^{\text {st }}, 61^{\text {st }}, 88^{\text {th }}, 89^{\text {th }}$, $90^{\text {th }}, 91^{\text {st }}$. Navy, Marine Corps aviation and naval infnatry forces are also under the command of the Northern Theater, which is also the biggest force in the Chinese Navy.

Central Theater Command has no external borders, and it is responsible for the security of the capital city. Mainly, all major innovations are tested in the military units operating under this command ${ }^{28}$. This command consists of the following components ${ }^{29}$ :

- $81^{\text {st }}$ Group Army composed of the $7^{\text {th }}, 70^{\text {th }}, 162^{\text {nd }}, 189^{\text {th }}, 194^{\text {th }}, 195^{\text {th }}$ combined armed brigade, $81^{\text {st }}$ artillery brigade, one army aviation and other combat support brigades.

- $82^{\text {nd }}$ Group Army composed of the $6^{\text {th }}, 80^{\text {th }}, 151^{\text {st }}, 188^{\text {th }}, 196^{\text {th }}, 205^{\text {th }}$ combined arms brigades, $82^{\text {nd }}$ artillery brigade, one army aviation, and other combat support brigades.

- $83^{\text {rd }}$ Group Army composed of the $11^{\text {th }}, 58^{\text {th }}, 60^{\text {th }}, 113^{\text {rd }}, 129^{\text {th }}, 193^{\text {rd }}$ combined arms armies, $83^{\text {rd }}$ artillery brigade, one army aviation, and other combat support brigades. This army is also in charge of the $161^{\text {st }}$ airborne combat force, and has an exceptional status.

The $112^{\text {nd }}$ Mechanased Division is also under leadership of the Central Theater Command, which is an exceptional example of the old system. This Command consists of six aviation divisions : the $7^{\text {th }}, 13^{\text {th }}, 15^{\text {th }}, 19^{\text {th }}, 24^{\text {th }}, 36^{\text {th }}$, altogether 15 air regiment, and the $56^{\text {th }}$ aviation brigade. Aside from this, various other auxilary units are also under subordination of the Central Theater Command :

- Beijing Military garrison which consist of three divisions

- the $15^{\text {th }}$ air regiment corps (the $127^{\text {th }}, 128^{\text {th }}, 130^{\text {th }} 131^{\text {st }}, 133^{\text {rd }}, 134^{\text {th }}$ aviation regiment brigades, special purpose and other brigades and teams)

- The $34^{\text {th }}$ aviation division

- The Air Force experimental center with its five brigades. It is cleat that this command has many essential characteristics.

The Western Theater Command has two armies under its subordination ${ }^{30}$ :

- The $76^{\text {th }}$ Group Army which consists of the $12^{\text {th }}, 17^{\text {th }}, 56^{\text {th }}, 62^{\text {nd }}, 149^{\text {th }}$, and $182^{\text {nd }}$ Motorised Infantry Brigades, $76^{\text {th }}$ Artillery Brigades, one military aviation and other combat support brigades.

\footnotetext{
${ }^{28}$ Blasko, Tradition and Transformation in the PLA, 2013, Table 4.3, pp. 88-95.

${ }^{29}$ А. Храмчихин. Новая Великая китайская стена. 20.10.2017. http://nvo.ng.ru/forces/2017-1020/1_970_china.html

${ }^{30}$ Blasko, Tradition and Transformation in the PLA, 2013, Table 4.3, pp. 77-95; А. Храмчихин. Новая Великая китайская стена. 20.10.2017. http://nvo.ng.ru/forces/2017-10-20/1_970_china.html
} 
- $\quad$ The $77^{\text {th }}$ Group Army, which consists of the $39^{\text {th }}, 40^{\text {th }}, 55^{\text {th }}, 139^{\text {th }}, 150^{\text {th }}$, and the $181^{\text {st }}$ Motorised Infantry Brigades, the $77^{\text {th }}$ Artillery Brigade, one military aviation and other other combat support brigades.

- The Western Theater Command also has four aviation divisions : the $4^{\text {th }}$, $6^{\text {th }}, 20^{\text {th }}, 33^{\text {rd }}$, altogether 11 air regiments under its subordination as well as five aviation brigades : the $16^{\text {th }}, 109^{\text {th }}, 110^{\text {th }}, 111^{\text {th }}, 112^{\text {th }}$, and $178^{\text {th }}$ UAV Brigade.

The military force of Guizhou's region is also sometimes listed as part of the command, which has not been finally formed yet, and is currently under the command of ground forces. This force consists of approximately ten brigades and up to three division ${ }^{31}$.

The Southern Theater command is in charge of the Ground Forces including two Group Armies ${ }^{32}$.

- The $74^{\text {th }}$ Goup Army's constituent units include the $4^{\text {th }}$ Group Army, consisting of the $16^{\text {th }}, 125^{\text {th }}, 132^{\text {th }}, 154^{\text {th }}$ and $163^{\text {rd }}$ Motorised Infantry Divisions, the $74^{\text {th }}$ Artillery brigade, one military aviation other combat support brigades.

- The $75^{\text {th }}$ Group Army contitues from the $15^{\text {th }}, 31^{\text {st }}, 32^{\text {nd }}, 122^{\text {nd }}, 123^{\text {rd }}$ Mechanized Infantry Divisions, the $75^{\text {th }}$ Artillery Brigade, one military aviation, and other combat support brigades. The $121^{\text {st }}$ Air Assault Brigade also operates under the command of this Army.

- Garrison troops of Hong Kong also operate under the command of the Southern Theater ${ }^{33}$, along with seven other combat support brigade. The air force command consists of five Air Assault Brigades : the $2^{\text {nd }}, 8^{\text {th }}, 9^{\text {th }}, 18^{\text {th }}, 44^{\text {th }}$, and seven aviation brigades: the $5^{\text {th }}, 54^{\text {th }}, 124^{\text {th }}, 125^{\text {th }}, 126^{\text {th }}, 130^{\text {th }}, 131^{\text {st }}$, and military UAV brigade. Naval forces, ships, naval air force, and naval infantry also operate under this Command. The Eastern Theater Command is the only one, which preserved the model of the former military district with its structure.

The Eastern Theater Command had the following units under its subordination ${ }^{34}$ :

- The $71^{\text {st }}$ Group Army which is in charge of the $2^{\text {nd }}, 35^{\text {th }}, 160^{\text {th }}, 178^{\text {th }}, 179^{\text {th }}$, and the $235^{\text {th }}$ Motorized Infantry brigade, the $71^{\text {st }}$ Artillery brigade, one army aviation and other combat support brigades ${ }^{35}$.

\footnotetext{
${ }^{31}$ The Military Balance 2018. Routledge, pp. 249-259.

${ }^{32}$ Dennis J. Blasko. §PLA Ground Forces: Moving Toward a Smaller, More Rapidly Deployable, Modern Combined Arms Force| The People's Liberation Army as Organization: Reference Volume v1.0, James C. Mulvenon and Andrew N. D. Yang eds. (Santa Monico: RAND; 2002), p. 329; A. Храмчихин. Новая Великая китайская стена. 20.10.2017. http://nvo.ng.ru/forces/2017-1020/1_970_china.html

${ }^{33}$ The Military Balance 2018: 249-259.

34 А. Храмчихин. Новая Великая китайская стена. 20.10.2017. http://nvo.ng.ru/forces/2017-1020/1_970_china.html

35 china-defense.blogspot.co.nz. Retrieved 18 July 2017.

http://china-defense.blogspot.com/2017/06/pla-orbat-reform-update-jun-2017.html
} 
- The $72^{\text {nd }}$ Group Army, where the $5^{\text {th }}, 10^{\text {th }}, 34$ th $, 85^{\text {th }}, 90^{\text {th }}$, and $124^{\text {th }}$ Motorized Infantry Brigades, the $72^{\text {nd }}$ Artillery brigade, one army aviation, and other combat support brigades operate.

- The $73^{\text {rd }}$ Group Army consisting of the $3^{\text {rd }}, 14 \mathrm{t}^{\text {h }}, 86^{\text {th }}, 92^{\text {nd }}, 145^{\text {th }}$ Motorized Infantry Brigades, the $73^{\text {rd }}$ Artillery Brigade, one army aviation, and other combat support brigades. Coastal Defense brigades also operate under the command of this army. The Air Force of the Eastern Theater Command consists of five aviation divisions : the $10^{\text {th }}, 14^{\text {th }}, 26^{\text {th }}, 28^{\text {th }}$, and $32^{\text {nd }}$, as well as the $9^{\text {th }}$ aviation brigade (the $7^{\text {th }}, 8^{\text {th }}, 9^{\text {th }}, 78^{\text {th }}, 83^{\text {rd }}, 85^{\text {th }}, 86^{\text {th }}, 93^{\text {rd }}$ and one transportational division), and UAV brigades.

The Eastern Naval forces and their branches operate under the leadership of the Eastern Theater Command.

Thus, the formation of above mentioned 13 army units in the Ground Forces have begun since 2017, which are considered to be strong armies. As we saw from the list, there are 12 brigades in each Army Group, out of which six are Motorized Infantry brigades and the other six are Combat-oriented brigades : Artillery, Army Aviation Regiment, Air Defense Brigade, Electronic-warfare troops, Special Operations Brigade, Engineering Corps, etc ${ }^{36}$. Special attention should be given to the fact that in all armies some military UAV brigades are being formed.

Combat-oriented brigades are all mechanized, and they are of three types : heavy, medium and light units. This categorization is mostly differentiated by the weight of armors. Alltogether, 20 out of 78 combat-orineted brigades are heavy, 30 are medium and the rest are light. These armies and brigades are rather independent and self-sufficient. Overall, there are 124 tanks in the brigades. The same way, battalions are also well-equipped and self-sufficient. There are four mixed battalions, one artillery battalion, one air defense battalion, one operational support battalion and a UAV battalion, etc. These battalions are very similar to that of the US battalion units. There are 31-40 tanks or armor, 36 artillery equipment and nine anit-tank equipment.

There is a powerful army aviation and a huge artillery within the army groups, especially in the BM-30 Smerch and in UAV brigades. These armies are similar in composition and functions to the Red Army strike brigades, except that the Chinese army. As a result of a close study of the American experience, PLA pays more attention to the interaction and harmonization of types of forces, and has a more effective digital control system.

The Chinese army has recently been conducting more large-scale ground exercises, with a special focus on the redeployment of large troops, large-scale application of Air force, missiles and other flying machines, etc.

${ }^{36}$ China Takes Bold Steps Toward Military Reform. Jan 11, 2016.

https://worldview.stratfor.com/article/china-takes-bold-steps-toward-military-reform 


\section{Strategic Support Force}

A close attention should be devoted to special troops in the Chinese army called Strategic Support Force. There is no similar military unit in any other army in the world. This newly-formed service branch has essential functions ${ }^{37}$ including strategic planning, space intelligence, ciberoperations, electronic-warfare service, etc $^{38}$. It was established in December of 2015 and currently has approximately 200.000 servicemen $^{39}$. For the first time in the real world we see the combination of virtual reality operations, cyber, and electronic-warfare operations in one military unit, which we think is an important innovation.

The following consolidations operate under this force ${ }^{40}$ :

- Jiuquan Satellite Launch Center / 20th Testing and Training Base

- Taiyuan Satellite Launch Center / 25th Testing and Training Base

- Xichang Satellite Launch Center/27th Testing and Training Base

- Wenchang Aerospace Launch Site

- Space Telemetry, Tracking, and Control Stations

- Space Research Centers

- Project Design Research and Development Center, etc.

As mentioned previously, Strategic Support Force troops also takes full responsibility for the operations in virtual space ${ }^{41}$. Combination of all forces and recources under one command was definately a crucial step, which was established in China following the example of the US. During 2009-2014 commander 'USCYBERCOM' was established in the US armed forces with a mission to direct and coordinate cyberspace operations.

Similarly, in the Chinese army there are multiple cyber-divisions, research centers, bureaus, translation and language centers, academies, etc. The number of bureaus with inexplicable functions is 12 with their separate center. From these subdivisions, the 56th, the57th, and the 58th are more or less known research centers $^{42}$. Those are special laboratories, where various kinds of robots are being created, and hacking and surveillance softwares are being designed. This divisions

37 China Takes Bold Steps Toward Military Reform. Jan 11, 2016.

https://worldview.stratfor.com/article/china-takes-bold-steps-toward-military-reform

${ }^{38}$ Yao Jianing. Expert: PLA Strategic Support Force a key force to win wars. 2016-01-06.

http://english.chinamil.com.cn/news-channels/pla-daily-commentary/2016-

01/06/content_6846500.htm

${ }^{39}$ The Military Balance 2018. Routledge, pp. 249-259.

${ }^{40}$ Costello, McReynolds 2018: 19-22; J. Costello.The Strategic Support Force: Update and Overview.December 21, 2016. https://jamestown.org/program/strategic-support-force-updateoverview/

${ }^{41}$ E. Kania. PLA Strategic Support Force: The 'Information Umbrella' for China's Military. Beyond cyber and space warfare, the SSF will play a key role in conventional joint operations. April 01, 2017. https:/thediplomat.com/2017/04/pla-strategic-support-force-the-information-umbrella-for-chinasmilitary/

${ }^{42}$ Costello, McReynolds 2018: 23-25. 
are also responsible for psychological and information performances. It is clear, that these functions are well-secured, thus the names, and the locations of the divisions are also kept in secret. Despite this fact, their quantity, geography and the combination of functions is extremely impressive. In the recent years, the Chinese army has increasingly demonstrated the ability of its troops to control network which is the success of this type of unit.

The next branch includes electronic-warfare subdivisions with clearer functions. There are several electronic-warfare brigades, settelite control and suppression systems, the $54^{\text {th }}$ research center, etc., operating under this command ${ }^{43}$.

PLA is making great strides in this regard and has adopted a clear policy. The point is that the Chinese army, being far behind that of the US in terms of satellites, as well as the fact that all US troops are extensively using satellite communication and command systems, the Chinese army is using this force to develope such kind of means and tactics, so that to be able to oppress the American systems in Space, in virtual space, and elswhere. In other words, they want to be able to switch off the American satellites and the Internet. As mentioned previously, there are electronic-warfare divisions operating within the troops and units of the Chinese army, and this branch of PLA is very powerful with enormous capabilities. It is responsible for digitalization of the Chinese army, creation of net-centric systems, based on satellite and other technologies.

This branch simultaneously centralizes space, cyber, electronic, and psychological warfare means and capabilities. We are sure, that controlling all the funtions at the same time and from the same center is very important, and that it can significantly increase the efficiency of functions.

At the same time we need to mention that, the inclusion of many other funtions, such as military astronautics, nuclear research, etc, can significantly complicate the work of the system, reduce the flexibility of the troops, and so on when operation under a general unit.

In addition, we need to mention that the Chinese army still maintains its highly centralized political leadership, like the Red Army did. As mentioned above, the real leadership of the Chinese army is exercised not by the Ministry of Defense but by the Central Military Council.

The establishment of this structure was not over yet when the Chinese military-political elite started talking about the need to totally abandon the model of territorial or theatrical command from the Soviet system and move to the US military command. At present, this issue stays relevant in China, as the logic of other reforms in the Armed forces itslef moves in this direction.

In a situation like this, when there are such dangers, as well as a powerful ground force and a growing economy with a high demand in China, it is difficult to claim that all the problems are only in the Pacific Ocean and predict that all the

${ }^{43}$ Costello, McReynolds 2018: 26-27. 
conflicts are to take place there. The Chinese geopolitical school also talks about the Asian recources.

\section{Results}

So, the increasing vulnerability of military bases located in the immediate vicinity of the theater, capabilities to hit large surface ships and CSGs with ballistic and long-range cruise missiles without entering air-defense zone, development of joint

air-defense system, as well as the potential loss or weakening of spacebased key capabilities can qualitatively change the capacity of American military potential. Such actions can be enhanced by other threats such as aggressive electronic cyber-attacks on centralized command and control nods, communication networks, and computer systems and on the US intelligence.

Certainly, one could hardly neglect all these concnerns because today's reality is that China is intensively developing both its offensive and defensive potentials, creating weapons and new means of warfare; and obviously by doing so it is rapidly reducing its own backwardness from the American Armed Forces, which used to exist after the Cold War. On the other hand though, the tradition of rapidly and fully assessing their potential opponents' capabilities, even with some exaggeration, fits the culture of the American military culture. They use this technique both for developing their own projects, and for contributing to the improvement of the Armed Forces. So, here it is worth analyzing everything in terms of use of concrete forces available. It is clear that this hypothetical collision will occur near the Chinese shores and will involve allies from both sides. Surely, the main operating military types will be the Navy and the Air Force, overhead imagery and communication systems; engagement of other combat arms will be limited, otherwise, which is unlikely, it might grow into a world war with the use of a nuclear weapon.

Currently, The US Air Force has approximately 600 twin-engine tactical fighters "F-15", "F-22" of the fourth and the fifth generation. Of course, not all of them are combat-effective at once; the majority of those fighters might be decommissioned by 2025 , but the vast majority will still have combat efficiency which will be replaced with more powerful aircrafts after the abovementioned period. They can be deployed to the Pacific zone after a short period of time. The radius of their flight makes more than 600 miles with no extra tanks, and if with additionals fuel tanks, they can cover ranges of up to 800 miles with about 4-5 tons of payload. This number of aircrafts should be added by 200 similar fighters when we speak about Japan and South Korea, not to mention Australia. If added aircrafts from the latter, this number will approximately increase up to 900. Here we don't count American heavy bombers, as well as 500 Navy fighters similar to "F-18E/F", out of which about 200-300 can be concentrated in this region. So, all together it can constitute up to 1200-1300 heavy bombers.

China, in purely quantitative terms, can contrast with about 400 twin-engine fighters with a ratio of 2.5-3/1. But that's not the only issue. As noted by some 
American experts, Chinese fighters have the same flight range. Mainly those are old and new fighters of Russian "Su-27" family or Their Chinese modification of "J-11". Even having the same flight range as the American fighters, they still yield the top place to American platfroms by some capabilities. First, this aircraft cannot carry the same amount of payload; they can carry an amount of payload equal to that of the American fighters only when in "air-to-air" mode, but as multipurpose aircraft they remain behind in their armament: they have poor aiming equipment and a limited range in air fights with regards to both radards and missiles. Chinese Air Force is especially weak in refueling and airborne control systems which makes it impossible to fight in a modern air battle. It is true that refueling in the air is a hard task, but it is much harder to hit an air refueling base, or to damage a land airport especially when that air-controlled base is protected by a great number of their own rechargable fighters. Compared to that of Chinese and Russian fighters, American fighters have 50-60 km of range advantage only thanks to the missiles. Chinese fighter jets cannot carry "air-to-surface" missiles with an operational range such as "AGM-158 JASSM", "AGM-154A JSOW", and "AGM-84E SLAM", and are firing two or more missiles launched from ordinary fighters. American fighter jets with similar missiles can have operational range of up to 1000 miles. These missiles are launched without entering Chinese ground air-defense area. Consider the fact, that we haven't counted one-engined fighters for both sides, which are large in number but have problems with their operational radius and armament carrying. Despite this fact, American "F-16" fighters significantely surpass their Chinese competitors; meanwhile the new generation "F-35" fighters beyond comparison altogether. This single-engined fighter jet can carry combat payload within a combat radius of 640-760 miles ${ }^{44}$. No other Chinese single-engined fighter has this capability. We need to take into account the fact, that all types of American fighter jets have a greater capability to refuel in the air, as a result they can operate from further distances, stay longer in the air, and keep their own ships out of the return fire zone.

Capabilities of the American Army are as follows: it plans to have the ability to lounch missiles for 30-50 days even if the number of launches is up to 1000 cruise missiles per day ${ }^{45}$. The Air Force and the Navy together already have about 2000

" AGM-158 JASSM " multifunctional cruise missiles of various types

1. about "AGM-154A JSOW" multifunctional cruise missiles

2. about 1000 "AGM-84E SLAM" missiles.

The same programm includes about 5000 sea and air launching large cruise missiles ("BGM-109", "AGM-86"), with a flight range of 500-2500 km. Today, Navy alone has 3000 long-range cruise missiles, and by 2025 this number will

\footnotetext{
${ }^{44}$ G. North. Vice President Customer Requirements Lockheed Martin Aeronautics http://www.fisher.org.il/2016/Adir\%20Powepoint/GaryNorth.pdf\#page=7

45 Лавренов 2005, 80.
} 
reach up to 6000 units $^{46}$. According to other information, today the Navy has 4000 cruise missiles which in can reach up to 7000 in the future. Mainly, these are missiles launched from American submarines, and Chinese Fleet in general is unable to compete with them. Some experts are concerned that the American Navy can be monitored and subjected to attacks. Of course, those possibilities cannot be excluded but still there are some gaps here. First, it is possible to detect, but we know that it is not easy to detect the world's most powerful underwater fleet (altogether the number of such fleets is about 50 and they carry over 1000 longrange cruise missiles). Second, even after detecting them, it is not easy to hit a large aircraft carrier, as:

- this class of warships are armed with the world's most reliable and powerful anti-missile system called "Aegis"

- the American fleet is still equipped with the most powerful detection systems, and even in case of mutual pressure on each other, which might cause disruption of some systems of both sides, the American warships will have the advantage beacuse they dominate in numbers and they have more advanced and accomplished network.

- Practically, no ballistic missile has hit any aircraft carrier so far. The Chinese missile mentioned above still has to demontrate its reliability.

- Generally speaking, Chinese Navy and Air Force confront a much bigger problem: lack of experience. On contrary, The US Navy and Air Force at least have some level of experiecne compared to the Chinese Military Force, who have no experiecne at all.

- It is practically proven, that these kind of ships cannot be hit and sunk immediately even when carrying one ton of combat payload. Besides, the aircraft on the deck can take off and complete their mission.

- The US main surface ships can launch their missiles from about 1000-1500 $\mathrm{km}$ off the coast "BMG-109", and "Tomahawk Block IV" missiles have 900-1000 mile or $1600 \mathrm{~km}$ launching range ${ }^{47}$ :

- Submarines can do it from a closer distance as they are hard to detect.

It is important to mention that the Chinese side also has problems with fleets ; they are inferior to US Pacific fleet with regards to the number and the total tonnage of ships. Moreover, if we take into concideration allies' fleets : Japan, South Corea, Australia and others, then this difference multiplies in a negative sense.

The Chinese fleet has almost no aircraft carriers; there is no way that only two similar aircraft carriers of Soviet model can compete with American ships. On contrary, the US Navy con concentrate up to 8 aircraft carriers in this area apart from amphibious ships. Chinese Navy has no cruisers, and in terms of quality and

\footnotetext{
${ }^{46}$ Алещин, Попов, Пучнин 2016/7: 12-14.

${ }^{47} \mathrm{http}: / /$ www.navy.mil/navydata/fact_display.asp?cid=2200\&tid=1300\&ct=2
} 
quantity, their destroyers are inferior even to the Japanese Navy. It is true, that Chinese Navy is rapidly producing a new-generation "Type 055 destroyer" which just like the newest American ships is more of a cruiser with a dicplacement of 12.000 tons. These ships can carry up to 128 various missiles, among them 4-6 are already put in use, but their capabilities are yet to be tested. At the same time, the production of a more advanced "Type 052D destroyer" warship continues the total number of which does not exceed 30. It is inferior to Japanese "Atago class" and partially to "Akizuki-class destroyer" almost in all its fighting qualities, a number of which exdeeds 30 . Undoubtadely, the number of above-mentioned Chinese ships is growing but paralelly the number of the competitors rises, too. It is useless to even try and compare them with that of the American "Arleigh Burke class" warships, as almost all the experts unanimously claim them to be the very best of their kind in the world. Chinese submarines, the number of which increases as well, can have problems with only the Japanese fleet not to mention the South Korean one.

Altogether, Chinese surface fleet has 1400-1500 anti-ship and anti-ait missiles / the 10 percent of which is able to hit the coastal targets, or surface ships that are within $250 \mathrm{~km}$ of distance. At the same time, Japanese ships have almost the same type and the same amount of missiles, excluding the South Korean ships. It is true, that the general launching range of Japanese anti-ship missiles is partially inferior to the armament of recent Chinese destroyers, but compared with other warships it even surpasses them.

Temporarily, The US fleet can concentrate up to 45 destroyers out of its 60 in the Pacific ocean, hence providing more than 4000 anti-ship, SAM, and other missiles capable of carrying out strikes to costal areas which by all technical means surpass that of Chinese fleet missiles. This number does not include about 14001500 similar missiles, which can be launched from the American cuisers and about 1000 long-range cruise missiles ready to be launched from submarines.

Thus, as a response to its $1400-1500$ sea-based missiles and approximately the same number of ground-based missiles, China can get about 6000 American marine platform-based missiles and about the same amount of ground-based missiles, out of which cruise and long-range surface-to-air missiles have an absolute advantage in all types of technical performance. To these, you need to add about 2000-3000 "AGM-86", "AGM-158 JASSM", and "AGM-84E SLAM" cruise missiles that can be launched from American bombers and from a certain amount of fighters. Thus, the actual ratio becomes three to four.

The US Air force and Navy can confront 400 Chinese fighters which will mainly operate withour aerial refuelers and airborne control systems. As mentioned previously, the US Air Force and Navy can confront up to three times more fighters with its 40 airborne control systems and aerial refuelers. Chinese airborne control systems are scarce in numbers and air refuelers are old with short-range capability with a lack of experience in such kind of operations. 


\section{Conclusion}

To sum up, Chinese army is developing rapidly and acquiring a new generation of military equipment: airborne control systems, high-precision weapons, auto-control systems, space technologies, etc. All these tools are the components of NPC warfare. In fact, China is the second country after the US that pays great attention to the technical and organizational toolkit of these kind of warfares. Of course, those American experts who warn of the rise of China, make careful and important observations. In reality, this country is enlarging its military budget year after year by creating new weapons, and mastering the auto-control systems. In fact, it is repeating the achievements of the American military forces, and even trying to surpass it. The US strategical security considers all these facts, and all the warnings come to confirm that. It is no coincident that the US-JapanSouth Korea trio is a serious concern for the other $\operatorname{side}^{48}$. Today, the Chinese influene continues to grow in the other parts of the world, in particular in Africa and in Central Asia.

Artsrun Hovhannisyan

Military Analyst

arcrunhovhannisyan@gmail.com

\section{BIBLIOGRAPHY}

\section{Documents}

2014-2043. Washington, DC: DoD, May 2013. 30 November. 2016. OSD, Quadrennial Defense Review 2014, p. 40. 1 Ibid., pp. 29-30.

N. Friedman. The U.S. Navy of 2030, Defense, Spring 2012. 30 November. 2016.

Chapter 8, PLA Ground Forces, by Dennis J Blasko, in The People's Liberation Army as Organisation, RAND, CF182.

The Military Balance 2018. Routledge, pp. 249-259.

Books

Лавренов С. 2005: Война XXI века. Стратегия и вооружение США, Москва, стр. 320.

Blasko D. J. 2001: "PLA Force Structure: A 20-Year Retrospective", in Seeking Truth from Facts, ed. James C. Mulvenon and Andrew N.D. Yang (Santa Monica, CA: RAND); $320 \mathrm{p}$.

Christman R. 2014: China's Second Artillery Force, in P. Dutton, A. Erickson, and R. Martinson (Eds.). China's Near Seas Combat Capabilities, China Maritime Studies, No 11, Newport, RI: Naval War College Press, February, 146 p.

Costello J., McReynolds J. 2018: China's Strategic Support Force: A Force for a New Era. Washington, D.C. October, 84 p.

Erickson A. 2011: Beijing's Aerospace Revolution, $\|$ in Andrew Erickson and Lyle Goldstein, (Eds.), Chinese Aerospace Power. Annapolis, MD: Naval Institute Press, $512 \mathrm{p}$.

\footnotetext{
${ }^{48}$ В. Путин: Военный альянс США и Японии вызывает наше беспокойство. 6 июня 2019. https://regnum.ru/news/2643056.html
} 
Martinage R. 2014: Toward a New Offset Strategy, Washington DC. 94 p.

OSD, Military and Security Developments Involving the People's Republic of China 2013, p. 92.

PLA Second Artillery Corps. The Science of Second Artillery Campaigns. Beijing: PLA Press, 2004, $460 \mathrm{p}$.

Articles

Алещин О. В., Попов А. Н., Пучнин В. В. 2016/7: Военно-морская мощь России в современных геополитических условиях, ВМ, стр. 12-14.

Chang A., Dotson J. 2016: Indigenous Weapons Development in China's Military Modernization, Staff Research Report, Washington, DC: U.S.-China Economic and Security Review Commission, April 5, 2012, p. 23; 30 November. Stokes, China's Evolving Conventional Strategic Strike Capability, p. 2.

Minnick Wendell 2014: China Developing Capability to Kill Satellites, Experts Say, Defense News, August 4, pp. 12-24.

Montgomery B. Evan 2014: Contested Primacy in the Western Pacific: China's Rise and the Future of U.S. Power Projection, International Security, Vol. 38, No. 4, Spring, pp. 115-149.

Ochmanek D. 2014: The Role of Maritime and Air Power in DoD's Third Offset Strategy. CT-420, Santa Monica, CA: RAND Corporation, December, p. 15.

Perrett B., Sweetman B., Fabey M., U.S. Navy Sees Chinese HGV as Part of Wider Threat. Aviation Week \& Space Technology. Retrieved 2018-12-14.

On-line sources

А. Храмчихин. Новая Великая китайская стена. 20.10.2017. http://nvo.ng.ru/forces/2017-10-20/1_970_china.html

В. Путин: Военный альянс США и Японии вызывает наше беспокойство. 6 июня 2019. https://regnum.ru/news/2643056.html

17.11.14 Китайский радар ҮJ-26 способен обнаружить F-22, http://www.militaryparitet.com/ttp/data/ic_ttp/7072/

China Takes Bold Steps Toward Military Reform. Jan 11, 2016.

https://worldview.stratfor.com/article/china-takes-bold-steps-toward-military-reformE.

Kania. PLA Strategic Support Force: The 'Information Umbrella' for China's Military. Beyond cyber and space warfare, the SSF will play a key role in conventional joint operations. April 01, 2017. https://thediplomat.com/2017/04/plastrategic-support-force-the-information-umbrella-for-chinas-military/

February-1. http://eng.mod.gov.cn/TopNews/2016-02/01/content_4638960.htm

china-defense.blogspot.co.nz. Retrieved 18 July 2017.

G. North. Vice President Customer Requirements Lockheed Martin Aeronautics http://www.fisher.org.il/2016/Adir\%20Powepoint/GaryNorth.pdf\#page=7

K. NAKAZAWA. Xi declares victory over old rivals Jiang, Hu. FEBRUARY 11, 2016. https://asia.nikkei.com/Features/China-up-close/Xi-declares-victory-over-old-rivalsJiang-Hu

Kopp, Carlo. Evolving Technological Strategy in Advanced Air Defense Sys-tems, „Joint Forces Quarterly, Issue 57, 2nd Quarter 2010, p. 93. 30 November. 2016. $<$ http://www.dtic.mil/doctrine/jfq/jfq-57.pdf $>$

J. Costello.The Strategic Support Force: Update and Overview.December 21, 2016. https://jamestown.org/program/strategic-support-force-update-overview/ 
Martinage, Robert. Toward a New Offset Strategy: Exploiting U.S. Long-Term Advantages to Restore U.S. Global Power Projection Capability. Center for Strategic and Budgetary Assessments (CSBA), Wshington, DC: October 27, 2014, p. 23. http://csbaonline.org/uploads/documents/Offset-Strategy-Web.pdf

O'Rourke, Ronald. China Naval Modernization: Implications for U.S. Navy Capabilities, RL33153, Congressional Research Service (CRS) Report for Congress, Washington, DC: CRS, February 2014, pp. 5-6. https://www.fas.org/sgp/crs/row/RL33153.pdf>

President Xi announces establishment of five PLA theater commands. 2016-

Stokes, Mark. China's Evolving Conventional Strategic Strike Capability: The anti-ship ballistic missile challenge to U.S. maritime operations in the Western Pacific and beyond. Arlington, VA: Project 2049 Institute, September 14, 2009, p. 2. 30 November. $<\mathrm{http}$ ://project2049.net/documents/chinese anti_ship_ballistic_missile_asbm.pdf $>$

U.S.-China Economic and Security Review Commission. 2013 Report to Congress. Washington, DC: GPO, November 20, 2013, p. 233. 30 November. 2016. $<$ http://www.uscc.gov/Annual_Reports/2013-annual-report-congress>

Yao Jianing. Expert: PLA Strategic Support Force a key force to win wars. 2016-01-06. http://english.chinamil.com.cn/news-channels/pla-daily-commentary/201601/06/content 6846500.htm

Yoskihara, Toshi. - Chinese Missile Strategy and the U.S. Naval Presence in Japan: The Operational View from Beijing, Naval War College Review, Vol 63, No 3, Summer 2010. 30 November. 2016. https://www.usnwc.edu/getattachment/69198ee2-edc24b82-8f85-568f80466483/Chinese-Missile-Strategy-and-the-U-S--Naval-Presen http://china-defense.blogspot.com/2017/06/pla-orbat-reform-update-jun-2017.html https://worldview.stratfor.com/article/china-takes-bold-steps-toward-military-reform http://china-defense.blogspot.com/2017/09/pla-orbat-update-northern-theater.html https://worldview.stratfor.com/article/china-takes-bold-steps-toward-military-reform http://www.navy.mil/navydata/fact_display.asp?cid=2200\&tid=1300\&ct=2

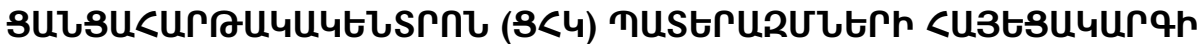

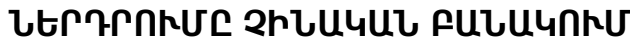

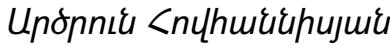

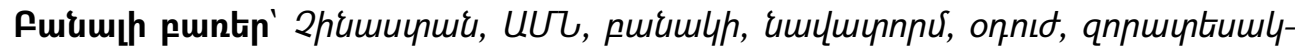

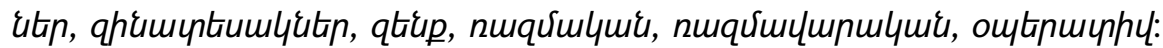

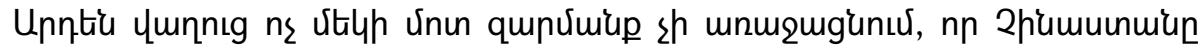

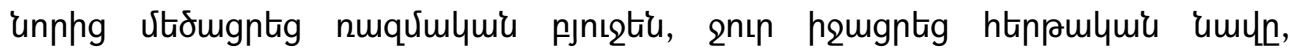

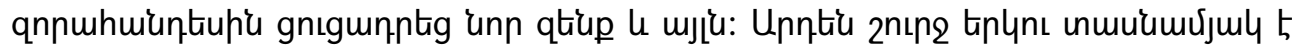

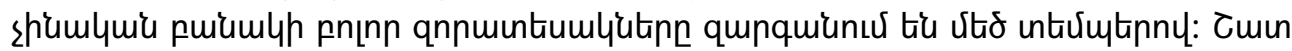

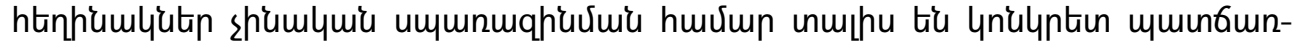

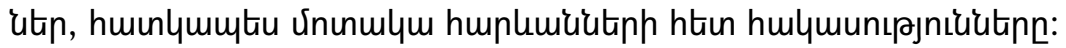

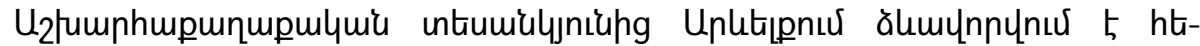

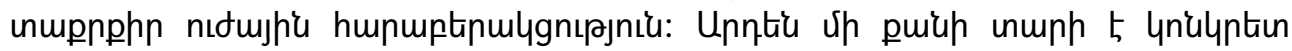




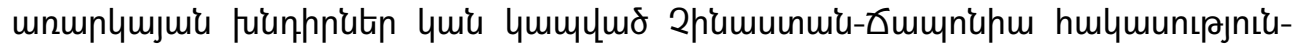

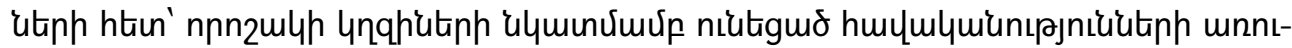

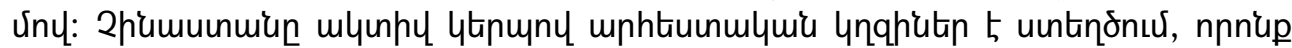

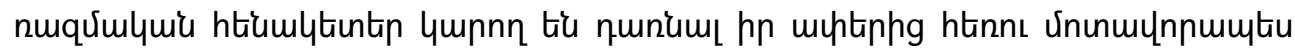

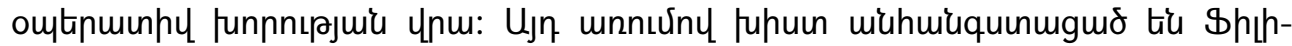
mhiuktinn u Uhtiunumun:

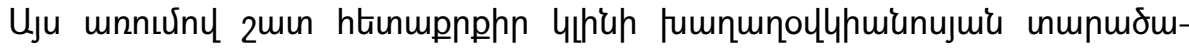

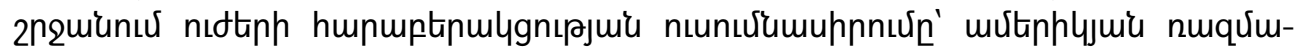

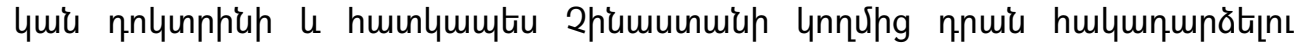

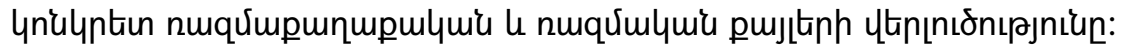

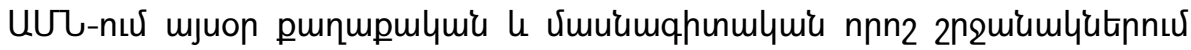

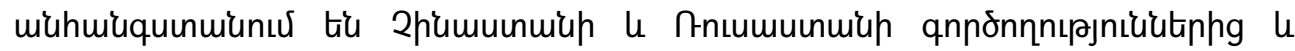

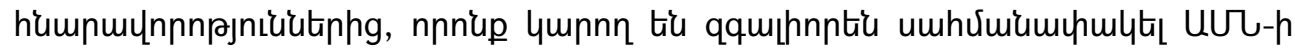

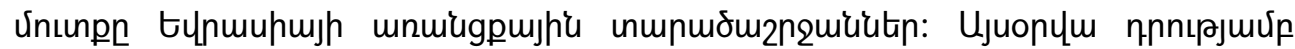

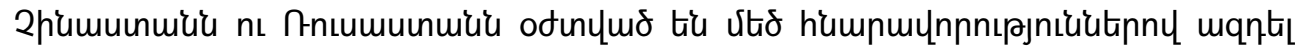

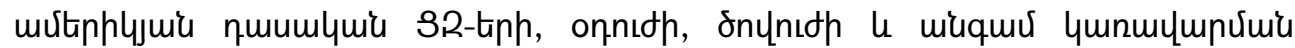

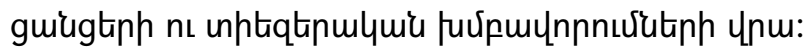

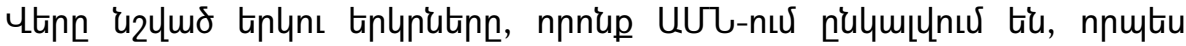

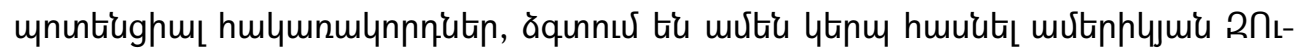

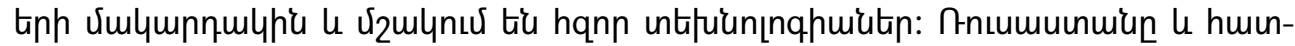

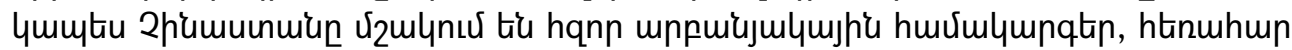

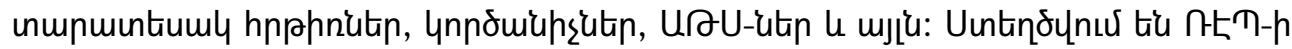

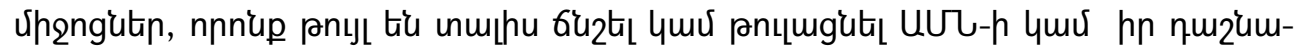

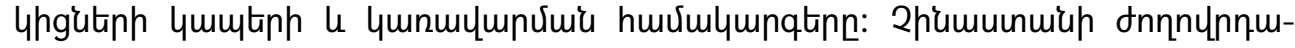

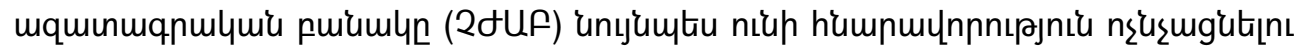

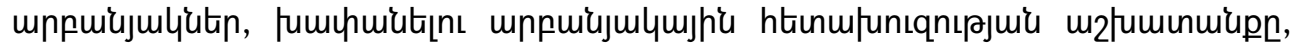

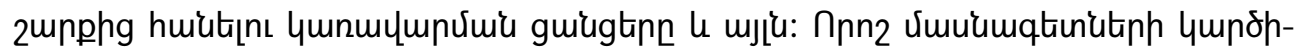

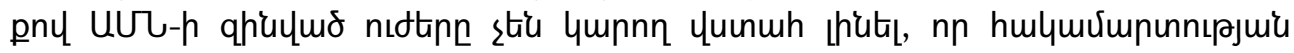

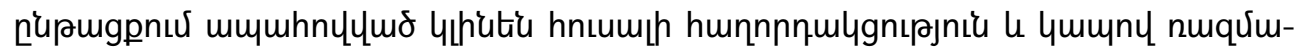

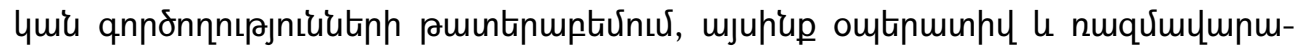
ymi vimlumnulynu: 